\title{
AGRICULTURAL AND ENVIRONMENTAL FUNCTIONS OF SUSTAINING LAND USE IN POLISH PROTECTED MOUNTAIN AREAS
}

Kamila Musial ${ }^{1}$, PhD; Wieslaw Musial ${ }^{2}$, Prof.

${ }^{1}$ National Research Institute of Animal Production, Department of Production Systems and Environment, ul. Krakowska 1, 32-083 Balice, Poland, email:kamila.musial@izoo.krakow.pl; ${ }^{2}$ University of Agriculture in Krakow, Department of Agricultural Economics and Organisation, Institute of Economic and Social Sciences, al. Mickiewicza 21, 31-120 Krakow, Poland

Abstract. The main purpose of the paper was the analysis and evaluation of the economic and natural significance as well as the functions of protected areas within three mountain ranges in Poland. These are: Carpathians, Sudetes and Swietokrzyskie Mountains, where in total there are located 182 rural and rural-urban municipalities, that characterize different shares of individual forms of nature conservation.

Key words: protected areas, functions of mountain areas, southern Poland.

JEL code: Q5, Q57.

\section{Introduction}

The knowledge of environmental values of a specific area, gained through a thorough examination of their structure and resources, is the basis for the rational use of specific space for economic purposes, at the same time retaining its most precious natural elements. Although, Poland is described as a lowland country, with mountain regions located in the south, it is the latter that tend to have more valuable natural resources. For this reason, various forms of nature conservation have been established in such areas (Kondracki J., 2009; Musial W., and Musial K., 2017).

The subject of study was evaluation of various legal forms of protected areas with regard to the assessment of significance of farmlands in rural and rural-urban municipalities in Polish mountain regions. The studied area included three main mountain ranges: the Carpathians, the Sudetes and the Swietokrzyskie Mountains. From the administrative point of view, they cover 5 voivodships. Analysis of data from the Main Statistical Office for the period 2012-17 covered a total of 182 municipalities, with regard to the proportion of protected farmlands, with the indication of specific forms of nature conservation. The analysis included: national and landscape parks, nature reserves, protected landscape areas and those parts of the Natura 2000 network that are not included in other forms of nature conservation. The number of such forms and their share in the individual mountain ranges and voivodships was defined on the basis of data for the year 2019 shared by the General Directorate for Environmental Protection. What was noted was the role of these areas, the dominant types in individual voivodships and how the share of such areas changed in the period between 201217.

The analysis also covered the layout of these areas as regards the so called vertical distribution of the land use, especially in the areas where the landscape includes high altitudes above the sea level and major differences in relative altitudes. The evaluation covered a number of municipalities as well as the area and proportion of the legally protected land within individual mountain ranges, as well as their main agricultural and natural functions. Adjusting the study to the current institutional division mandatory in agricultural policy, the studied areas were broken down into: mountain areas, foothill areas and partial foothills (PROW, 2007-13). A mountain area is understood as an area where more than $50 \%$ is situated higher than 500 m above the sea level, foothill area has more than $50 \%$ of the area situated higher than $350 \mathrm{~m}$ above the sea level, but lower than $500 \mathrm{~m}$ above the sea level, while partial foothills have less than $50 \%$ of the area below $350 \mathrm{~m}$ above the sea level. In order to illustrate a natural framework, these divisions were superposed on vegetation belts, within which it is possible to identify some economic layers as well. 
The purpose of the paper was the analysis and evaluation of the economic and natural significance as well as the functions of protected areas within three mountain ranges in Poland.

\section{Research results and discussion}

\section{Functions of mountain areas in Poland}

Although, agricultural production in the mountains used to provide a wide range of services, its significance in many regions is becoming gradually reduced. This inspires questions about a new place and position of agriculture in the mountain areas in Poland (Heldak M., 2008). It is possible to distinguish three main functions, which are important for mountains: economic, environmental and social (Czudec A., 2013). One of the reasons why the productive function of agriculture in the mountains is reduced is its low competitiveness, and this is due to difficult natural conditions, low intensity and lower cost-efficiency (Kata R., 2010). On the other hand, mountain areas in Poland are a valuable natural asset, and sustaining their economic functions is important also to maintain the proper role of natural environment. This meaning of functions is a specific sort of benefit, which follows both from the natural conditions and from the intentional management of the environment and agricultural production. These functions may be the same as those of other regions, or separate and characteristic of the individual areas: in this case, these are mountain areas.

Among the most important agricultural functions, food production should be mentioned in the first place, both conventional and of a higher quality (Fig. 1). Since subregions of Carpathians are highly populated, livestock production is significant for the local and regional markets as well (Knapik J., and Musial K., 2017). This entails farming livestock of local breeds and livestock grazing in the mountains. Especially in the Carpathians, local breeds of cattle and sheep are maintained, adjusted to the specific local conditions. For many centuries, dairy and meat products have been produced here in the form of various traditional and local specialties, which is a result of keeping that ruminants (Molik E., Dobosz J., Kordeczka K., and Peksa M., 2017). Since the mountain areas in Poland are situated in the moderate climate zone and mostly on moderate altitudes, they are a good place to produce biomass for animal feed. The biomass comes in a variety of natural and seminatural grasslands and agrocenoses. In the foothills, the most important is production of usable legume species, cereal, fruit and vegetables grown, with the help of extensive technologies. This is why a significant problem is the maintenance of agricultural, open mountain areas in the production space, i.e. mountain areas shaped historically and environmentally, forming a kind of landscape with a high share of farmlands (Musial K., Szewczyk W., and Grygierzec B., 2015).

Mountains also have important environmental functions, which constitute the daily experience of both, the inhabitants of these areas and tourists. Since the annual average precipitation is higher and water retention is low, these are spring areas for most of the major Polish rivers. Thanks to a variety of existing habitats, which follows mainly from the vertical shape of the area, an important environmental function of the mountains is maintaining high biodiversity. The most specific element of this diversity, which is a decisive factor of the natural identity especially in the Carpathians, are endemics (Mirek, Z., and Piekos-Mirkowa, H., 2009; Zemanek B., 2009). These taxa are usually species and subspecies, whose range is limited to a very specific, small area: in this case, it would be the Tatra mountains, especially their higher parts. From among 2500 local species and subspecies of the Polish vascular plants, 170 are endemics or subendemics, which makes up about $7 \%$ of the national flora. Most of these are encountered in mountains, because in order to classify and identify them we need certain geographical barriers and spatial isolation (Piekos-Mirkowa, H., and Mirek, Z., 2010). It is also a factor behind the existence of rare animal species. The total image is 
complemented by the maintenance of the cultural landscape, which includes seminatural plant formations, such as pastures and meadows in the lower and upper montane belt. Their structure and physiognomy depend on the maintenance of ruminants, especially the local breeds (Musial K., and Kasperczyk M., 2013; Knapik J., and Musial K., 2017).

Other functions of the mountains include: various economic services, social and demographic functions, and cultural and historical ones. Economic functions include i.a. obtaining and processing wood, the production of aggregates and construction materials, as well as providing location for nonagricultural companies. Such activities are often opposed to the traditional understanding of agriculture and therefore give rise to conflicts of environmental and economic interests. Both in Poland and in most of the affluent countries in Western Europe, mountains are regions with considerable demographic burden, because people willingly inhabit such areas. However, it also happens that such regions are subject to depopulation, like the Sudetes in the second half of the 20th century (Latocha A., 2009). People living in the mountain areas usually display considerable cultural distinctness, which is related to the fact that these areas used to be rather isolated in the past. Nowadays this is a factor determining the cultural capital of the region, often expressed in the attachment to the unique tradition (Musial K., 2018). This also entails strong attachment of the rural population to the land, which includes small farms, passed down from generation to generation (Musial W., 2017; Musial W., and Musial K., 2018). When confronted with the contemporary market economy, such behaviour is often reviewed, which impacts the way of using farmlands.

\begin{tabular}{|l|l|}
\hline Agricultural functions of mountains \\
\hline Producing conventional food \\
feed
\end{tabular}

Source: authors' study, 2019

Fig. 1. Main functions of mountain areas in Poland

\section{Significance of sustaining the agricultural use of land in protected mountain areas}

Apart from the high-mountain range of the Tatras which is of relatively small area, the Polish Carpathians cover the area of mid- and low mountains, such as Beskidy, Bieszczady and widespread foothills. The foothills are traditionally agricultural zone with a low proportion of woodlands (ca. 20$30 \%$ of the land). On the other hand, the Beskidy zone is situated on higher altitudes above the sea level. The dominant forms include steep slopes with a greater share of woodlands, i.e. between 30 and $70 \%$ (Starkel L., 1990; Bucala A., and Starkel L., 2013). The total area of the Polish Carpathians is ca. 19.5 thousand $\mathrm{km}^{2}$, i.e. $76.8 \%$ of the mountain area and ca. $6.3 \%$ of the area of the whole country (Twardy S., 1993). The Carpathians spread over three voivodships: Lesser Poland, Podkarpackie and Silesian. The Polish part of the Sudetes, including the foothills, occupies ca. 9.3 thousand $\mathrm{km}^{2}$ within the Lower Silesian voivodship. On the other hand, the Swietokrzyskie 
Mountains, situated in the Swietokrzyskie voivodship, include old, paleozoic fold structures. Since absolute and relative altitudes of this range do not match the definitions of mountains, its classification is about the geological structure rather than the actual landscape (Kondracki J., 2009).

Since the Carpathians are the mountain range that occupies the largest area in Poland, they include 141 rural and rural-urban municipalities with a total area of 14.55 thousand $\mathrm{km}^{2}$ (Tab. 1 ). The Sudetes include 34 municipalities with the total area of 3.98 thousand $\mathrm{km}^{2}$, and the small range of the Swietokrzyskie Mountains includes 7 such municipalities, which occupy a total of 0.73 thousand $\mathrm{km}^{2}$. With regard to the area of the farmlands covered with various forms of protection, the Figures are as follows: the Carpathians - 298.1 thousand ha, the Sudetes - 90.6 thousand ha, and the Swietokrzyskie Mountains - 28.5 thousand ha. In 2017, the total proportion of land subjected to legal nature conservation was respectively as follows: $76.0 \%, 27.2 \%$ and $92.6 \%$.

Table 1

\section{Number of municipalities with their area and the share of farmlands legally protected in the mountain regions}

\begin{tabular}{|c|c|c|c|c|c|c|}
\hline \multirow[t]{2}{*}{ Studied area } & \multirow{2}{*}{$\begin{array}{c}\begin{array}{c}\text { Total number } \\
\text { of } \\
\text { municipalities }\end{array} \\
2010\end{array}$} & \multirow{2}{*}{$\begin{array}{c}\begin{array}{c}\text { Total area } \\
\text { (thousand } \\
\text { km2) }\end{array} \\
2010\end{array}$} & \multirow{2}{*}{$\begin{array}{c}\text { Area of } \\
\text { farmlands } \\
\text { subject to } \\
\text { various forms } \\
\text { of protection } \\
\text { (thousand ha) } \\
2010\end{array}$} & \multicolumn{3}{|c|}{$\begin{array}{l}\text { Share of land subject to legal } \\
\text { protection in the total area } \\
(\%)\end{array}$} \\
\hline & & & & 2002 & 2012 & 2017 \\
\hline $\begin{array}{l}\text { Carpathians - } \\
\text { total }\end{array}$ & 141 & 14.55 & 298.1 & $74.6 \%$ & $71.4 \%$ & $76,0 \%$ \\
\hline Mountain area & 48 & 6.14 & 88.4 & $85.8 \%$ & $86.8 \%$ & $88,6 \%$ \\
\hline Foothills & 50 & 4.92 & 107.0 & $77.9 \%$ & $70.1 \%$ & $72,8 \%$ \\
\hline Partial foothills & 43 & 3.49 & 102.7 & $50.3 \%$ & $46.1 \%$ & $55,5 \%$ \\
\hline Sudetes - total & 34 & 3.98 & 90.6 & $31.0 \%$ & $25.2 \%$ & $27,2 \%$ \\
\hline Mountain area & 10 & 1.05 & 28.8 & $34.6 \%$ & $30.7 \%$ & $33,9 \%$ \\
\hline Foothills & 16 & 2.18 & 54.0 & $34.4 \%$ & $27.0 \%$ & $27,0 \%$ \\
\hline Partial foothills & 8 & 0.74 & 7.8 & $15.8 \%$ & $12.0 \%$ & $15,6 \%$ \\
\hline $\begin{array}{l}\text { Swietokrzyskie } \\
\text { Mts. - total }\end{array}$ & 7 & 0.73 & 28.5 & $79.4 \%$ & $92.7 \%$ & $92,6 \%$ \\
\hline Foothills & 1 & 0.06 & 2.0 & $88.8 \%$ & $88.8 \%$ & $87,0 \%$ \\
\hline Partial foothills & 6 & 0.67 & 26.6 & $78.5 \%$ & $93.1 \%$ & $93,1 \%$ \\
\hline $\begin{array}{l}\text { Total mountain } \\
\text { areas }\end{array}$ & 182 & 19.25 & 417.3 & $65.8 \%$ & $62.6 \%$ & $66,5 \%$ \\
\hline Poland & 2173 & 312.67 & 6113.0 & $33.0 \%$ & $32.5 \%$ & $32,5 \%$ \\
\hline
\end{tabular}

Source: authors' study (2019) based on: Musial W., Sroka W., further based on the Regional Data Base (GUS) and the National Agricultural Census (2012)

On various types of farmlands in mountain regions, several forms of environmental protection can be found, the most important of which are: national parks, natural reserves and landscape parks. In the analysed Polish regions there are 9 national parks (Tab. 2) covering $7.3 \%$ of a total area (Tab. 3). The largest share in the total size of the protected area, according to database of the Main Statistical Office (2012), is attributed to the areas of protected landscape together with the Natura 2000 (56.5\%) and the national landscape parks (35.2\%). Although in the mountain ranges natural reserves account for the largest representation of protected areas (in total 124), they frequently cover smaller surfaces, and their total share in such regions is only $1 \%$. 
Number of individual forms of legal protection within the mountain regions

\begin{tabular}{|l|c|c|c|c|c|}
\hline \multirow{2}{*}{ Studied area } & \multicolumn{6}{|c|}{$\begin{array}{c}\text { Number of individual forms of legal protection within the total } \\
\text { area (\%) in 2012 }\end{array}$} \\
\cline { 2 - 6 } & $\begin{array}{c}\text { National } \\
\text { parks }\end{array}$ & $\begin{array}{c}\text { Nature } \\
\text { reserves }\end{array}$ & $\begin{array}{c}\text { Landscape } \\
\text { parks }\end{array}$ & $\begin{array}{c}\text { Protected } \\
\text { Landscape } \\
\text { Areas }\end{array}$ & $\begin{array}{c}\text { Natura } \\
\mathbf{2 0 0 0} \\
\text { Areas }\end{array}$ \\
\hline Carpathians - total & $\mathbf{6}$ & $\mathbf{9 3}$ & $\mathbf{1 4}$ & $\mathbf{1 6}$ & $\mathbf{6 6}$ \\
\hline Podkarpackie voivodship & $2 *$ & 31 & 7 & 10 & 30 \\
\hline Lesser Poland voivodship & $5 *$ & 43 & 4 & 5 & 30 \\
\hline Silesian voivodship & 0 & 19 & 3 & 1 & 6 \\
\hline Sudetes - total & $\mathbf{2}$ & $\mathbf{2 6}$ & $\mathbf{8}$ & $\mathbf{3}$ & $\mathbf{4}$ \\
\hline Lower Silesian voivodship & 2 & 26 & 8 & 3 & 4 \\
\hline Swietokrzyskie Mts. - total & $\mathbf{1}$ & $\mathbf{5}$ & $\mathbf{0}$ & $\mathbf{0}$ & $\mathbf{1}$ \\
\hline Swietokrzyskie voivodship & 1 & 5 & 0 & 0 & 1 \\
\hline Total mountain areas & $\mathbf{9}$ & $\mathbf{1 2 4}$ & $\mathbf{2 2}$ & $\mathbf{1 9}$ & $\mathbf{7 1}$ \\
\hline
\end{tabular}

* Magurski National Park is situated in both: Lesser Poland and Podkarpackie voivodships

Source: authors' study based on Directorate General for the Environment Protection (2019), the forms are quoted for the mountain regions together with foothills.

Protected areas represent various shares in the area of the regions defined as mountains, foothills as well as partial foothills (Tab. 3). In case of the Carpathians and Sudetes, the largest share of national parks was found in the mountain regions: respectively $10.9 \%$ and $7.4 \%$. The Swietokrzyskie Mountains which, in fact, are rather of the upland character, had only two regions of observation, foothill and partial foothill, accounting for respectively $9.6 \%$ and $8.4 \%$ of the share of particular forms of environmental protection, in contrast to the total area of protected mountain regions in Poland.

Table 3

\section{Share of individual forms of nature protection in the total area of the mountain regions in Poland}

\begin{tabular}{|c|c|c|c|c|}
\hline \multirow[b]{2}{*}{ Studied area } & \multicolumn{4}{|c|}{$\begin{array}{l}\text { Share of individual forms of legal protection in the total area ( \%) } \\
\text { in } 2012\end{array}$} \\
\hline & $\begin{array}{l}\text { National } \\
\text { parks }\end{array}$ & Nature reserves & $\begin{array}{l}\text { Landscape } \\
\text { parks }\end{array}$ & Other forms* \\
\hline Carpathians - total & $7.4 \%$ & $0.9 \%$ & $33.8 \%$ & $57.9 \%$ \\
\hline Mountain area & $10.9 \%$ & $1.0 \%$ & $33.6 \%$ & $54.4 \%$ \\
\hline Foothills & $4.3 \%$ & $0.7 \%$ & $35.1 \%$ & $59.8 \%$ \\
\hline Partial foothills & $2.3 \%$ & $1.1 \%$ & $31.3 \%$ & $65.3 \%$ \\
\hline Sudetes - total & $5.8 \%$ & $1.4 \%$ & $57.9 \%$ & $34.9 \%$ \\
\hline Mountain area & $7.4 \%$ & $2.0 \%$ & $61.9 \%$ & $28.7 \%$ \\
\hline Foothills & $5.8 \%$ & $1.2 \%$ & $55.6 \%$ & $37.4 \%$ \\
\hline Partial foothills & $0.0 \%$ & $0.5 \%$ & $58.7 \%$ & $40.7 \%$ \\
\hline Swietokrzyskie Mts. - total & $8.5 \%$ & $0.8 \%$ & $24.2 \%$ & $66.5 \%$ \\
\hline Foothills & $9.6 \%$ & $0.0 \%$ & $44.2 \%$ & $46.1 \%$ \\
\hline Partial foothills & $8.4 \%$ & $0.9 \%$ & $22.4 \%$ & $68.2 \%$ \\
\hline Total mountain areas & $7.3 \%$ & $1.0 \%$ & $35.2 \%$ & $56.5 \%$ \\
\hline Poland & $3.1 \%$ & $1.6 \%$ & $25.7 \%$ & $69.6 \%$ \\
\hline
\end{tabular}

* other forms embrace first of all the areas of protected regions and the areas covered by the Natura 2000, which are not included in other forms of the nature conservation

Source: authors' study (2019) based on: Musial W., Sroka W., further based on the Regional Data Base (GUS) and the National Agricultural Census (2012)

On average, within the mountain areas, farmlands covered by any form of the environment protection embraced approximately $62 \%$. The largest share of this type of land was to be found in the Swietokrzyskie Mts. (over $90 \%$ ), and slightly smaller in the Carpathians and Sudetes. Moreover, significant diversity was observed within the particular mountain ranges, both within the Carpathians 
and Sudetes. And so, for the Carpathians, huge diversity was observed between their eastern part (Podkarpackie) and western part (Silesia), versus central regions covering areas within the Lesser Poland. In the first group almost in $90 \%$ of all municipalities, more than $50 \%$ of all farmlands are covered by some kind of environmental protection, whereas in the central part of the Carpathians the same share of municipalities with protected farmlands was considerably smaller.

\section{Rational land use on broad altitudinal range}

In all three main mountain ranges, the total share of protected lands depends on the vertical location of municipalities. The higher and vaster the range is, the larger the share of protected area. This is related to reduced opportunity to implement activities connected with agriculture, but also with specific, frequently unique, landscape and natural values. On the other hand, the analysis of the farmlands covered by various forms of environmental protection showed a lack of strict relationship between the altitude of the municipality's location and the increase in the number and size of the areas with specific forms of nature conservation. In Carpathians' municipalities, which are situated especially on higher altitudes, the percentage of farmlands is comparatively lower. This is due to the high afforestation rate and concentration of protected sites. On the other hand, reverse trends can be observed in the Sudetes, where the majority of protected areas are situated on the farmlands.

While analysing and estimating the agricultural use of land in mountain regions, including method of land development, intensity of agricultural production, and progressive changes, what should be considered in the first place, are the types of terrain and the vegetation belts, as these are strictly connected with the type of soil and intensity of precipitation. All these factors play a crucial role in shaping agricultural functions in mountain regions. They are diversified in relation to the three analysed mountain ranges. In order to present the schematic explanation of the general regularities of the rational land use in altitudinal range, there has been presented an example of the Carpathians, with a highest part - the Tatras (Fig. 2). In submontane belt, which is situated up to $600 \mathrm{~m}$ above the sea level, which according to the institutional division can be assigned as the part of the foothill region, vegetation type is similar to the vegetation of the surrounding lowlands. Above this altitude, there are only mountain belts, that in institutional division include mountain regions. These are composed of the two forest levels: lower montane belt (up to $1000 \mathrm{~m}$ ) and upper montane belt (up to $1350 \mathrm{~m}$ ), where in the Tatras, in the natural process develops the forest vegetation. In the lower montane belt dominate formations of deciduous trees, historically classified as Fagetum carpaticum - fertile Carpathian beech (Pawlowski B.,1977), currently classified as Dentario glandulosaeFagetum, which is a subendemic Carpathian plant association (Matuszkiewicz W., 2002). In the higher montane belt there is a coniferous forest, with the dominating Piceetum tatricum association. In the areas of human activity also seminatural vegetation can be found, which includes in both montane belts the hay meadows classified as endemic association of Gladiolo-Agrostietum capillaris. From the upper montane zone, typically highland vegetation start dominating, as the associations of Adonestyletum alliariae and Aconitetum firmii, in the subalpine belt (Matuszkiewicz W., 2002).

In deciding to introduce agriculture to the mountain regions, humans were bound to adjust their ways to the general regularities of the stratified composition of the soils, climate and vegetation, therefore various types of the environment use have been arranged in the characteristic economic layers. In the Carpathians and the Sudetes, within their low and medium foothills which are the most valuable for agriculture, there is quite a wide range of choice between the agricultural production in the form of green farming and arable lands, where cereals and potatoes are grown. Lower mountain region is less important for agriculture, yet shepherding gradually begins to dominate there, while 
the regions from the upper montane zone up to the peak level are beyond the agricultural interest and so are dominated by shepherding likewise.

\begin{tabular}{|c|c|c|c|c|c|}
\hline Altitudinal range & $\begin{array}{l}\text { Altitude } \\
\mathrm{m} \text { above } \\
\text { sea level }\end{array}$ & $\begin{array}{l}\text { Vegetation } \\
\text { belts }\end{array}$ & $\begin{array}{c}\text { Economic } \\
\text { layers }\end{array}$ & $\begin{array}{l}\text { Agricultural } \\
\text { significance }\end{array}$ & Vegetation types / land use \\
\hline \multirow{2}{*}{ High mountains } & $\begin{array}{l}\text { Above } \\
2200\end{array}$ & subnival belt & \multirow{2}{*}{ none } & \multirow{2}{*}{$\begin{array}{l}\text { of no significance } \\
\text { for agriculture }\end{array}$} & \\
\hline & ca. 2200 & alpine belt & & & \\
\hline $\begin{array}{l}\text { Mid-high mountains } \\
\text { with steep slopes }\end{array}$ & $\begin{array}{l}\text { up to } \\
1680 \mathrm{~m}\end{array}$ & subalpine belt & \multirow{2}{*}{ pasturage } & \multirow{2}{*}{$\begin{array}{c}\text { valuable only for } \\
\text { pasturage }\end{array}$} & \\
\hline $\begin{array}{l}\text { Mountains with } \\
\text { moderately steep } \\
\text { slopes }\end{array}$ & up to $_{1350 \mathrm{~m}}$ & $\begin{array}{l}\text { upper montane } \\
\text { belt }\end{array}$ & & & \\
\hline $\begin{array}{l}\text { Low and mid- } \\
\text { mountains }\end{array}$ & $\begin{array}{l}\text { up to } \\
1100 \mathrm{~m}\end{array}$ & $\begin{array}{c}\text { lower montane } \\
\text { belt }\end{array}$ & hay meadows & $\begin{array}{l}\text { valuable mainly for } \\
\text { pasturage }\end{array}$ & \\
\hline $\begin{array}{c}\text { Mid and high } \\
\text { foothills with gentle } \\
\text { slopes }\end{array}$ & $550-600$ & \multirow[t]{2}{*}{$\begin{array}{l}\text { submontane } \\
\text { belt }\end{array}$} & $\begin{array}{l}\text { growing oats } \\
\text { and potatoes }\end{array}$ & $\begin{array}{l}\text { valuable for } \\
\text { agriculture and } \\
\text { convenient for } \\
\text { pasturage }\end{array}$ & \\
\hline Low foothills & $500-550$ & & $\begin{array}{l}\text { growing rye } \\
\text { and wheat }\end{array}$ & $\begin{array}{l}\text { highly valuable for } \\
\text { agriculture }\end{array}$ & \\
\hline
\end{tabular}

Source: authors' study, based on Pawlowski (1972) and Starkel (1990)

Fig. 2. Rational use of land in various types of: terrain, altitudinal range and within various vegetation belts (example of the Carpathians)

Rational use of the land in lower foothills is balance or near-balance, therefore there should be ca. 50 \% green farming and 50 \% arable land (Starkel L., Pietrzak M., and Lajczak M., 2007). Forests may have quite a significant role when there is a considerable share of slopes and unfavourable terrain such as ravines and landslides. In case of the high foothills, the rational land use is valuable for both agriculture and shepherding. Recommended rates for the land use are: 30-40 \% for the forests, app. 30-40 \% for green farming and around 20-30 \% for the crop rotary agriculture. In turn, higher mountain levels, in so called medium mountains, encompassing lower montane belt, increase unfavourable conditions for agricultural production with the use of plow. Therefore, the arable land account for only minimum share. Due to the existence of the associations of hay meadows, those areas are particularly valuable for breeding animals, including shepherding. In the structure of the farmland use, also where the landscape is dominated by forests accounting for 60-70\% of the area, there are various types of permanent grasslands. However, in recent years such proportions underwent considerable changes. With the decrease in the number of ruminants, some parts of the pastures undergo succession and visible changes occur in the borderline between farmlands and forests (Fatyga J., and Gorecki A., 2001). The final beneficiary of these changes are new woodlands, where progressive afforestation and growth of shrubs frequently approach residential areas.

\section{Conclusions}

The share of the areas covered with the various forms of nature conservation, in rural and ruralurban municipalities, serve as the evidence to the fact that the natural potential of the mountain regions in Poland is significant. The role of protected areas is connected with the maintenance of specific landscape values and biodiversity. Yet, in the opinion of the inhabitants, the use of the farmlands especially those covered with environmental protection programme, mainly seminatural meadows and pastures, is a factor which impedes the functioning and development of the agricultural production. Moreover, considerable share of the areas covered with various forms of environmental protection means numerous limitations of the possible agricultural use of the land, which 
consequently limits the economic growth of particular farms. Although the issues caused by the coexistence of various forms of nature conservation as well as economic and agricultural activities in the mountain regions are similar to those in other parts of the country, yet in the mountains they become increasingly more important due to their larger scope.

Therefore, it is in those mountain regions, where such functions of economic benefits, brought by agricultural areas and those emerging from natural landscape beauty, should be implemented in a particularly reasonable way. Agricultural functions of mountains such as: biomass production, grazing ruminants and local food processing, are well adjusted to the priorities for the environmental function of the mountains. In order to ensure the environmental functions and the protection of the mountains, they are covered intensely by various forms of environmental and landscape protection. In the Polish mountain regions, up to $66.5 \%$ of the area is covered by various forms of nature conservation, which constitutes twice the average value for the whole area of Poland. Apart from the forest areas, whose share is positively correlated with the height above the sea level, agriculture is still a crucial factor and the beneficiary of the mountain regions. Its important role, beside this of agricultural and economic nature, is to protect the seminatural ecosystems. Additionally, agriculture and in particular shepherding maintain the cultural landscape, prevent unfavourable changes on the borderline between farms and forests and foster biodiversity. Withdrawing the agricultural usage, particularly shepherding in the higher belt of the mountains, poses threat to the status quo of the agricultural and forest areas.

\section{Bibliography}

15. Bucala, A., Starkel, L. (2013). Postepujaca recesja rolnictwa a zmiany w srodowisku przyrodniczym polskich Karpat. Przeglad Geograficzny, No. 85 (1), pp. 15-29.

16. Czudec, A. (2013). Wielofunkcyjnosc rolnictwa gorskiego i podgorskiego (na przykładzie Bieszczad i Beskidu Niskiego). Polish Journal of Agronomy, No. 13, pp. 3-9.

17. Heldak, M. (2008). Przemiany funkcjonalne obszarow wiejskich Sudetow po integracji z Unia Europejska. Infrastruktura i Ekologia Terenow Wiejskich, PAN, No. 8, pp.91-102.

18. Fatyga, J., Gorecki, A. (2001). Ksztaltowanie granic rolno-lesnej i darniowo-polnej w Sudetach, IMUZ, Falenty.

19. Kata, R. (2010). Sytuacja ekonomiczno-finansowa gospodarstw rolnych polozonych w regionie gorskim. [in:] Czynniki ksztaltujace konkurencyjnosc regionu gorskiego (na przykladzie polskich Karpat); red.: Czudec A., Wyd. UR Rzeszow, Rzeszow, pp. 121-148.

20. Knapik, J., Musial, K. (2017). Multifunkcjonalnosc chowu owiec - proba nowego ujecia problemu. Roczniki Naukowe Zootechniki, No. 44 (2), pp. 161-175.

21. Kondracki, J. (2009). Geografia regionalna Polski. Warszawa PWN, ed. III completed, pp. 273-368.

22. Latocha, A. (2009). Zmiany krajobrazu wiejskiego w Sudetach w okresie powojennym. Polskie Krajobrazy Wiejskie Dawne i Wspolczesne, Prace Komisji Krajobrazu Kulturowego, No. 12, pp. 130-138.

23. Matuszkiewicz, W. (2002). Guidebook to Labelling Plant Habitats in Poland. Warszawa PWN, ed. III., pp. 3294.

24. Mirek, Z., Piekos-Mirkowa, H. (2009). Fitogeograficzne aspekty endemizmu w Polsce. Wiadomosci Botaniczne, No. 53(3/4), pp. 7-30.

25.11. Molik, E., Dobosz, J., Kordeczka, K., Peksa, M. (2017). Cultural Sheep Grazing in the Tatra National Park as Example of Management Consistent with the Principles of Sustainability. Problems of Small Agricultural Holdings, No. 1, pp. 61-70.

26. Musial, K. (2018). Cultural Sheep Grazing in the Area of Two Carpathian National Parks, Tatra and Pieniny. Wiadomosci Zootechniczne, No. 56 (2), pp. 30-37.

27. Musial, K., Kasperczyk, M. (2013). Changes in Floristic Composition of the Mountain Pasture Sward After the Abandonment of Sheep Grazing. The role of grasslands in green future. Proceedings of the 17th Symposium of the Europaean Grassland Federation. Akureyri, Island, pp. 345-348.

28. Musial, K., Szewczyk, W., Grygierzec, B. (2015). The Effect of Ceasing of Use on the Flora and Plant Associations in Meadows and Pastures of Selected Parts of the Western Carpathians. Fragmenta Agronomica. No. 32 (4), pp. 53-62.

29. Musial, W. (2017). Problems of the Agriculture in the Polish Carpathians, Yesterday and Today-revisiting a 1913 Brochure for the Peasants of Podhale. Problems of Small Agricultural Holdings, No. 3, pp. 97-108. 
30. Musial, W., Musial, K. (2017). Nastepstwa dezagraryzacji w sferze produkcyjnej i ekologicznej na przykladzie wybranych powiatow wojewodztwa podkarpackiego. Roczniki Naukowe Stowarzyszenia Ekonomistow Rolnictwa i Agrobiznesu, No. 19 (5), pp. 149-157.

31. Musial, W., Musial, K. (2018). Economic and Ecological Potential of the Protected Areas in the Pieniny Mountains. Proceedings of the International Conference „Economic Science for Rural Development”, No. 49, pp. 48-55.

32. Pawlowski, B. (1972). Szata roslinna gor polskich [w:] Szafer W. Szata roslinna Polski. T. II, pp. 189-201.

33. Piekos-Mirkowa, H., Mirek, Z. (2010). Threat to Endemic Vascular Plants Occurring in Poland and Their Conservation. Chronmy Przyr. Ojcz., No. 66 (1), pp. 15-26.

34. Rural Development Programme. (2014). Ministry of Agriculture and Rural Development.

35. Starkel, L. (1990). Ewolucja srodowiska przyrodniczego Karpat w okresie dzialalności czlowieka. Problemy Zagospodarowania Ziem Gorskich, No. 29, pp. 34-46.

36. Starkel, L., Pietrzak, M., Lajczak, M. (2007). Wplyw zmian uzytkowania ziemi i wzrostu czestotliwosci ekstremalnych opadow na obieg wody i erozje oraz ochrone zasobow przyrodniczych Karpat. Problemy Zagospodarowania Ziem Gorskich, No. 54, pp. 19-31.

37. Twardy, S. (1993). Warunki przyrodnicze a uzytkowanie ziemi w Karpatach. Postepy Nauk Rolniczych. No. 3, pp. 51-60.

38.Zemanek, B. (2009). Phytogeographical Problems of the Carpathians. Roczniki Bieszczadzkie, No. 17, pp. 43-58. 